\title{
EGFR NP_005219.2:p.P753_1759del
}

National Cancer Institute

\section{Source}

National Cancer Institute. EGFR NP 005219.2:p.P753 I759del. NCI Thesaurus. Code C98581.

A deletion of seven amino acids from the epidermal growth factor receptor protein from the proline at position 753 through the isoleucine at position 759 . 